Everyday Life 
This page intentionally left blank 


\title{
Everyday Life
}

A Poetics of Vernacular Practices

\author{
Roger D. Abrahams
}

\section{PENN}

University of Pennsylvania Press Philadelphia 
Copyright (C) 2005 University of Pennsylvania Press

All rights reserved

Printed in the United States of America on acid-free paper

$\begin{array}{llllllllll}10 & 9 & 8 & 7 & 6 & 5 & 4 & 3 & 2 & 1\end{array}$

Published by

University of Pennsylvania Press

Philadelphia, Pennsylvania 19104-4011

Library of Congress Cataloging-in-Publication Data

Abrahams, Roger D.

Everyday life : a poetics of vernacular practices / Roger D. Abrahams.

p. $\mathrm{cm}$.

ISBN 0-8122-3841-9 (cloth : alk. paper)

Includes bibliographical references and index.

1. Culture-Semiotic models. 2. Manners and customs. 3. Anthropological linguistics. I. Title.

GN357.A27 2005

$306^{\prime} .01-d c 22$

2004061152 
This book is for Archie Green, a mensch for the ages, the poet of vernacular practices, and a masterful if unknowing marriage-broker. This is not the Big Book we dreamed about, but a testimony to the breadth and depth of an ancient friendship. 
This page intentionally left blank 